\title{
A Note on the Texts and Kant Referencing
}

All citations to the works of Immanuel Kant will contain the bibliographical information and page references of the English translation as well as the reference information for Kants gesammelte Schriften, edited by the Royal Prussian Academy of Sciences (referred to as the Akademie edition). As is standard practice, the Akademie reference will immediately follow the page number given for the English translation. The Akademie reference will be encased within brackets at the end of the citation and will provide the volume number and page number [volume number: page(s)]. For example, [8:310] or [8:310-13]. The following translations for Kant's works have been used:

Hans Reiss (ed.) and H. B. Nisbet (trans.), Kant's Political Writings (Cambridge: Cambridge University Press, 1970). This collection of essays includes Kant's: (1784) "Idea for a Universal History with a Cosmopolitan Purpose," (1784) "An Answer to the Question: 'What is Enlightenment?," (1793) "On the Common Saying: This May be True in Theory, But it Does not Apply in Practice," (1795) "Perpetual Peace: A Philosophical Sketch," and (1798) "The Contest of Faculties." In all instances, references to these essays by Kant will be related to this collection.

Immanuel Kant (1785), Grounding for the Metaphysics of Morals, James W. Ellington (trans.), (Cambridge: Hackett Publishing Company, 1993). In all instances, references to this work by Kant will be related strictly to this translation. 
Immanuel Kant (1787), The Critique of Pure Reason, J. M. D. Meiklejohn (trans.), (New York: The Colonial Press, 1900). In all instances, references to this work by Kant will be related strictly to this translation. Nevertheless, it should be noted that an appendix from this text ("Transcendental Logic II, Dialectics, I, I: Of Ideas in General") is referenced without a page number for the Meiklejohn translation. This is due to the fact that the appendix appears in this translation without a page number at the end of the volume. Therefore, when citing from this appendix, I have only given the volume and page number from the Akademie edition. All other references to this translation will contain both the translation page number and the Akademie edition numbers.

Immanuel Kant (1790), Critique of Judgement, J. Meredith (trans.), (Oxford: Oxford University Press, 1973). In all instances, references to this work by Kant will be related strictly to this translation.

Immanuel Kant (1797), The Metaphysics of Morals, Mary Gregor (trans.), (Cambridge: Cambridge University Press, 1996). In all instances, references to this work by Kant will be related strictly to this translation.

Immanuel Kant (1798), Anthropology from a Pragmatic Point of View, Victor Lyle Dowdell (trans.), (Carbondale: Southern Illinois University Press, 1978). In all instances, references to this work by Kant will be related strictly to this translation.

Lastly, it should be noted that key philosophical terms and concepts are represented in italics in their first usage (for example, kingdom of ends) so as to highlight that the phrasing is intentional and that the term is an idea associated with the author/debate being discussed. 